\title{
The Impact of Top-Down Communication on Career Satisfaction
}

\author{
Eylem Şimşek, Turkish Air Forces, Turkey
}

\begin{abstract}
Organizational communication includes both interpersonal relationship and information exchange process by different levels. As an independent variable, organizational communication influences both organizations and individuals. This study aimed to investigate the impact of top-down communication on career satisfaction. The sample consisted of 205 office managers, executive assistants and secretaries working in different sectors in Istanbul. 16 cases were excluded due to missing data. The data form 189 participants were analyzed. Career Satisfaction Scale (Greenhaus, Parasuraman \& Wormley, 1990) and Top-Down Communication Scale (Downs \& Hazen, 1977) were data collection instruments. The quantitative paradigm, including descriptive, relational, and comparative models was employed. In analyzing data, a set of correlation, analysis of variance, and multiple regression techniques were employed. Results reveal that top-down communication is positively and significantly correlated with career satisfaction $(r=.457, \mathrm{p}<.01)$. Top-down communication explains $20.9 \%$ of the variance on career satisfaction. Institution explains additionally $4.7 \%$ variance on career satisfaction. Top-down communication was categorized as low and high topdown communication scores. When top-down communication groups compared, significant mean differences of career satisfaction were found. As age, occupation, institution, educational level and years in the present group differ, significant mean differences both on top-down communication and career satisfaction is found.
\end{abstract}

Various interactions of organizational communication dimensions with individual and organizational factors are found out day by day. It is clear that organizational communication contributes not only to the performance and effectiveness of the organization but also the attitudes, values, behaviors of the individuals within the organization (Simsek, 2011). Organizational communication consists of both individual and interpersonal communication levels. This study aims to evaluate organizational communication in terms of interpersonal hierarchical relationship. Organizational communication forms employee's attitudes towards the organization. This study examined whether top-down communication affects employees' career satisfaction evaluations.

Keywords: organizational communication, top-down communication, career satisfaction 


\section{Organizational Communication}

Organizational communication is commonly defined as a process by which activities of a society are collected and coordinated to reach the goals of both individuals and the collective group (Business Dictionary, 2015). Container and social constructive approaches discuss organization and communication interactions differently. The container approach towards organizational communication assumes that organizations serve as containers that influences communication behavior. Organization and communication exist separately. Organizational structure has effect on the communication practices. In contrast, social constructionist approach claims that communication creates the form and the shape of organizations. Even the information flow practices could form a centralized or decentralized organizational structure (Commgap, 2008). In this study, organizational communication practices were evaluated as the independent variable. This means that organizational communication affects organization and their members, consistent with the social constructionist approach.

Components of organizational communication are classified differently. Putnam and Cheney (1985) determined main organizational communication focus areas as information flow and channels, climate, superior-subordinate and network analysis. Allen, Gotcher and Seibert (1993) determined 17 organizational communication areas: interpersonal communication, communication skills, culture and symbolism, information flow and channels, power and influence, decision making and problem solving, communication networks, communication and management styles, organization-environment interface, technology, language and messages, structure, uncertainty and information adequacy, groups, ethics, cross-cultural and climate (Deetz, 2000). Technology, social media, and discourse were new fields related to organization communication researches.

The functions of organizational communication could be categorized as to inform, regulate, integrate, manage, persuade, and socialize organizational members/organizations. Inform means providing necessary information. Regulate is related to management issues. Integrate is defined as left hand knows what the right hand is doing, meaning coordination. The management function is associated with achieving organizational goals. Persuasion is generally evaluated between supervisors and subordinates or peers. Socialize refers to being integrated into the communication networks (Richmond, McCroskey, \& McCroskey, 2005). 
This study focused on the quality of super ordinate-subordinate communication. The reason for that is top-down communication interacts with all of the organizational communication functions,

Top-down communication is historically has been one of the main issues of organizational communication. In many organizations, the flow of the information has been designed hierarchically like monitoring and controlling duties (Friebel \& Raith, 2004). Especially organizational communication theories were based first on classical management theories, emphasizing managerial hierarchy. Transmitting information from high level towards lower ones was the case. Top-down communication is only a tool for maintaining the structure.

Human relations perspective, developed from the results of Mayo experiment known with 'the Hawthorne effect", focused first on the individuals and the importance of the interactions of employees, which causes need satisfaction. Human resources approach attempts to achieve high performance and productivity by viewing each person as a valuable human resource. Top-down communication is an obligation to attain the organizational goals. Employee participation in decision making is a part of this strategy. Systems approach assumes that individuals in organizations achieve more than they can independently. Top- down communication is a part of this system. An interruption in top-down communication could affect the whole organization.

Cultural approach gives importance to the shared values and beliefs, common practices, skills, and actions, rules, objects and artifacts, and mutually understood meanings. Cultural approach was developed due to the success of Japan firms. According to this approach, the quality of the top-down relationship and other organizational communication practices determines the organization itself (Hahn, Lippert, \& Paynton, 2014). The success of an organization mostly depends on its organizational communication practices; including relationship, information exchange and positive culture and climate. Generally the higher hierarchy level determines and maintains the directions and the quality of organizational communication. Therefore, topdown communication secures sufficient information flow across hierarchical levels and organizational units. According to the Brandes and Darai's (2014) experimental research, topdown communication between managers and their subordinates resolves uncertainty about the work. They pointed out that a lack of top down communication could be associated with reduced organizational performance. Top-down communication is suggested to be developed 
in order to increase employee performance in the presence of uncertainty. Supervisor support is a kind of positive top-down communication experience. Demirhan, Kula and Karagöz (2014) reported that supervisor support is related to job satisfaction and performance.

The importance of the top-down communication quality measured by leadership styles on employee satisfaction was questioned by Donald Pelz (1952). Pelz effect explained that instead of leadership style, the power of the manager is more effective for downward communication. Morgan and Schieman (1983) stressed that most of the employees felt their organization are not successful in downward communication based on a survey of 30,000 employees. Only \%40 of the managers, $\% 39$ of the professionals, $\% 32$ of the clericals and $\% 26$ hourly workers evaluated downward communication as good or very good. Larkin and Larkin (1994) highlighted that downward communication is most effective if top managers communicate directly with immediate supervisors and immediate supervisors communicate with their staff. Jablin (1980) indicated that top managers could follow-up by communicating with employees directly, depending on the importance of the issue (cited in Baker, 2002, p. 7). Interpersonal communication is under the umbrella of organizational communication, considering top-down communication research. From the need perspective, interpersonal communication fulfills pleasure, affection, inclusion, and relaxation needs. When these interpersonal needs could not be satisfied, loneliness, anxiety or dissatisfaction would most likely be experienced. Communication needs could be influenced by the political, cultural, economic, social environment and social- psychological environment like social background, life position, and psychological characteristics, satisfaction etc. (Rubin \& Rubin, 1992). To sum up, interpersonal communication part of organizational communication affects the need fulfillment process. Positive top-down communication serves like managerial/organizational support. Therefore, top-down communication or downward communication is thought to be related with employees' organizational evaluations like career satisfaction.

\section{Career Satisfaction}

Career satisfaction is defined as the positive psychological or job related outcomes/success perception based on individual job experience. The achievement level of the predetermined career goals determines career satisfaction (Yüksel, 2005). Linked with motivation theories, career satisfaction has both individual and organizational aspects. External career satisfaction 
factors are salary, promotions etc. and inner satisfaction factors are individuals perceptions and evaluations (Avcı \& Turunç, 2012).

Career satisfaction could be evaluated as higher level organizational needs. The aim of career management could be associating organizational and individual expectations (Aktas, 2014). Career satisfaction is significantly related to many organizational variables such as performance (Greenhaus et al., 1990), turn-over (Joo \& Park, 2010).

The main purpose of the present study is to examine the impact of top-down communication on career satisfaction concerning some demographic variables. Toward this purpose, answers are sought to the following questions:

What are the levels of top-down communication satisfaction and career satisfaction? Is the correlation between top-down communication satisfaction and career satisfaction is significant?

1. How much of the career satisfaction is explained by demographics and top-down communication scores?

2. Are there any significant differences in top-down communication satisfaction and career satisfaction, when demographic data differentiated?

3. Are the any significant differences in career satisfaction of more satisfied and less satisfied employees regarding top-down communication?

\section{Methods}

\section{Model}

A quantitative approach of scientific inquiry was employed. Descriptive, relational, and comparative models were used to examine interactions between top-down communication satisfaction and career satisfaction. The research model and the variables of the study are presented in Figure1. As can be easily deduced from the illustration, the impact of top-down organizational communication on employees' career satisfaction is investigated in reference to demographics. 


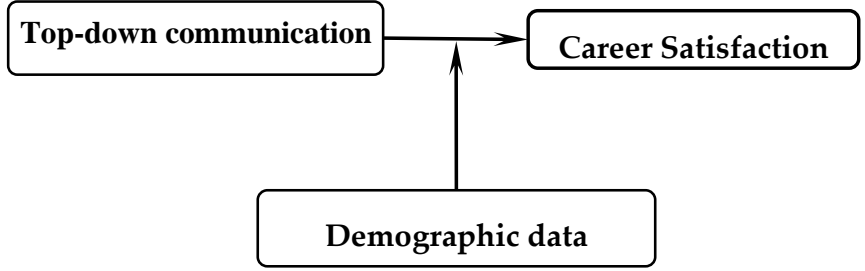

Figure 1. Research Model

\section{Sample}

The data from the 205 office managers, executive assistants and secretaries working in different sectors in Istanbul, Turkey were collected. The scope of this study consisted of service, education and health sector. After missing value analysis, 16 cases were deleted. There is no any univariate and multivariate outlier. Data from 189 (110 female and 79 male) employees were analyzed. The descriptive statistics of the sample were presented below considering gender, marital status, age, education, occupation, sector, institution, years in occupation, and years in the present organization

Gender: Male, 79 participants (41.8\%); female, 110 participants (58.2\%).

Marital status: Single, 90 participants (47.6\%); married, 99 participants (52.4\%).

Age: 18-24 years old, 35 participants (18.5\%); 25-29 years old, 57 participants (30.2\%); 3034 years old, 47 participants (24.9\%); 34-39 years old, 31 participants (16.4\%); 40 +years old, 19 participants $(10.1 \%)$.

Education: High school, 45 participants (23.8\%); associated degree, 92 participants (48.7\%); undergraduate, 32 participants (16.9\%); masters, 10 participants (5.3\%); doctoral, 10 participants $(5.3 \%)$.

Occupation: Office managers, 45 participants (23.8\%); secretaries, 113 participants $(59.8 \%)$, executive assistants, 31 participants (16.4\%).

Sector: Public sector, 90 participants (47.6\%); private sector, 99 participants $(52.4 \%)$. Institution: Education, 26 participants (13.8\%); service, 70 participants (37.0\%); health, 93 participants $(49.2 \%)$.

Years in occupation: 1-5 years, 86 participants (45.5\%); 6-10 years, 53 participants (28\%); 11-15 years, 31 participants (16.4\%); 16 and more years, 19 participants (10.1\%).

Years in the present organization: 1-5 years, 117 participants (61.9\%); 6-10 years, 39 participants (61.9\%); 11-15 years, 18 participants (9.5\%); 16 and more years, 15 participants $(7.9 \%)$. 


\section{Instruments}

Demographic Data Form: This form consisted of questions about gender, marital status, age, education, occupation, sector, institution, years in occupation, and years in the present organization.

Career Satisfaction Scale: Greenhaus, Parasuraman and Wormley (1990) developed this scale. Avc1 and Turunç (2012) translated career satisfaction scale into Turkish. Before the application, researcher and a SME controlled the items of the scale and some small adaptations were done. The Cronbach alpha reliability value of the career satisfaction scale in the present study was $\alpha$ $=.86$.

Top-Down Communication Scale: The communication with sub-ordinates factor of the Communication Satisfaction Questionnaire (CSQ) was implemented. CSQ was developed by Downs and Hazen (1977). Simsek (2011) translated this scale into Turkish. The reliability was found high $(\alpha=0.95)$. The Cronbach alpha of the scale in this study was $\alpha=.93 .9$.

\section{Results}

Demographics and top-down communication were independent variables, whereas career satisfaction is the dependent variable. The minimum, maximum, mean scores, standard deviations of top-down communication scores $(\mathrm{M}=2.94, \mathrm{SD}=1.14)$ and career satisfaction scores $(M=2.79, S D=1.04)$ were presented in Table 1. As seen in the table, the mean score of top-down communication satisfaction isfound to be higher than career satisfaction mean score.

Table 1. Descriptive statistics of top-down communication and career satisfaction

\begin{tabular}{llllll} 
& $\mathrm{N}$ & Min & Max & Mean & SD \\
\hline Top-down communication & 189 & 1.00 & 5.00 & 2.94 & 1.14 \\
Career satisfaction & 189 & 1.00 & 5.00 & 2.79 & 1.04 \\
\hline
\end{tabular}

Bivariate Pearson correlation was conducted in order to determine the relationship between topdown communication and career satisfaction. They are positively and significantly correlated $(\mathrm{r}=.457, \mathrm{p}<.01)$. As top-down communication increases, career satisfaction also increases. 
Table 2. The correlations of top-down communication and career satisfaction

Top-down com. Career Sat.

Top-down communication

1

Career satisfaction

$.457 * *$

1

*Significant mean differences at the .01 level

The impact of the top-down communication and demographic variables on career satisfaction was analyzed by a set of regression analyses. Regression results are illustrated in Table 3. For the first regression analysis, only top-down communication was regressed on career satisfaction. The explained variance by top-down communication on career satisfaction is $20.9 \%$, which is very high and significant. As top-down communication increases, career satisfaction also increases. For the second regression analysis, both top-down communication and demographic variables were regressed on career satisfaction. In addition to communication satisfaction, institution explains additionally $4.7 \%$ variance of career satisfaction.

Table 3. Regression Table (IV's: Demographic data, top-down communication, DV: career satisfaction)

\begin{tabular}{|l|l|l|l|l|l|}
\hline $\begin{array}{l}\text { Independent } \\
\text { Variables }\end{array}$ & \multicolumn{2}{|l|}{ Predictor(Uniuqe $\left.\mathbf{R}^{\mathbf{2}}\right)$} & Beta & $\mathbf{t}$ & Sig. \\
\hline $\begin{array}{l}\text { 1. Top-down } \\
\text { communication }\end{array}$ & $\mathrm{x} 1$ & Top down com $\left(\mathbf{R}^{\mathbf{2}}=. \mathbf{2 0 9}\right)$ & .46 & 7.03 & .000 \\
\cline { 2 - 6 } & $\mathrm{R}=.457, \mathbf{R}^{\mathbf{2}}=\mathbf{. 2 0 9}, \mathrm{F}(1,187)=49.47, \mathrm{p}<.001$ & .000 \\
\hline $\begin{array}{l}\text { 2. Demographic } \\
\text { data and top down } \\
\text { communication }\end{array}$ & $\mathrm{x} 1$ & Top down com $\left(\mathbf{R}^{\mathbf{2}}=\mathbf{. 2 0 9}\right)$ & .46 & 7.03 & .001 \\
\cline { 2 - 6 } & $\mathrm{x} 2$ & Institution $\left(\mathbf{R}^{\mathbf{2}}=\mathbf{. 0 4 7}\right)$ & -.24 & -3.42 & \\
\cline { 2 - 5 } & $\mathrm{R}=.506, \mathbf{R}^{\mathbf{2}}=\mathbf{. 2 5 6}, \mathrm{F}(2,186)=32.02, \mathrm{p} \leq .001$ & \\
\hline
\end{tabular}

The mean differences of the top-down communication and career satisfaction, depending on demographic data changes were tested by a set of variance analyses. Additionally, top down communication was categorized as satisfied and dissatisfied communication groups. Only significant differences were reported in Table 4.

Top-down communication means were significantly different, when age $[\mathrm{F}(4,184)=4.12$ $\mathrm{p}<.005]$, education $[\mathrm{F}(4,184)=.12, \mathrm{p}<.005]$, occupation $[\mathrm{F}(3,185)=18.38, \mathrm{p}<.001]$, institution 
$[\mathrm{F}(3,185)=20.56, \mathrm{p}<.001]$ and years in present organization $[\mathrm{F}(3,185)=4.55, \mathrm{p}<.001]$ groups changes. As age, educational level and years in the present organization increases, top-down communication means also increases significantly. Secretaries and health sector have less topdown communication.

Career satisfaction means differs significantly, in terms of the categories of age $[\mathrm{F}(4,184)=$ $3.35, \mathrm{p}<.05]$, education $[\mathrm{F}(4,184)=2.38, \mathrm{p}<.05]$, occupation $[\mathrm{F}(3,185)=17.9, \mathrm{p}<.001]$, institution $[\mathrm{F}(3,185)=18.46, \mathrm{p}<.001]$ and years in present organization $[\mathrm{F}(3,185)=18.46$, $\mathrm{p}<.001]$. Similar to top down satisfaction; as age, educational level and years in the present organization increases, career satisfaction also increases. Secretaries and health sector have less career satisfaction compared to the other occupations and institutions.

When top-down communication was grouped as satisfied and non-satisfied ones, depending on median score of 2.94. The career satisfaction scores of the group with low top-down communication scores $(\mathrm{M}=2.37, \mathrm{SD}=.84)$ is significantly low compared to the group with high top-down communication scores $(\mathrm{M}=3.23, \mathrm{SD}=1.04)$. The variance analysis result was found to be significant $[\mathrm{F}(1,187)=38.60, \mathrm{p}<.001]$. 
Table 4. Top-down communication and career satisfaction means and mean differences in terms of demographic variables

\begin{tabular}{|c|c|c|c|c|c|c|c|c|}
\hline \multirow[b]{2}{*}{ IV } & \multirow[t]{2}{*}{ DV } & \multirow[b]{2}{*}{$\mathbf{N}$} & \multicolumn{3}{|c|}{$\begin{array}{l}\text { Top down } \\
\text { communication }\end{array}$} & \multicolumn{3}{|c|}{ Career satisfaction } \\
\hline & & & Mean & SD & Sig/F & Mean & SD & Sig/F \\
\hline \multirow{2}{*}{ Gender } & Male & 79 & 2.93 & 1.06 & \multirow{2}{*}{ Not sign. } & 2.87 & 1.05 & \multirow{2}{*}{ Not tested } \\
\hline & Female & 110 & 2.95 & 1.21 & & 2.74 & 1.04 & \\
\hline \multirow{2}{*}{$\begin{array}{l}\text { Marital } \\
\text { status }\end{array}$} & Single & 90 & 2.86 & 1.11 & \multirow{2}{*}{ Not sign. } & 2.6910 & .97862 & \multirow{2}{*}{$\begin{array}{l}\text { Not } \\
\text { significant }\end{array}$} \\
\hline & Married & 99 & 3.01 & 1.17 & & 2.8832 & 1.09288 & \\
\hline \multirow{5}{*}{ Age } & $18-24$ & 35 & 2.66 & 1.095 & \multirow{5}{*}{$\begin{array}{l}F(4,184)= \\
4.12 \\
p<.005\end{array}$} & $2.61 *$ & .91 & \multirow{5}{*}{$\begin{array}{l}F(4,184)= \\
3.35 \\
p<.05\end{array}$} \\
\hline & $25-29$ & 57 & 2.80 & 1.12 & & $2.77 *$ & .98 & \\
\hline & $30-34$ & 47 & 2.76 & 1.21 & & 2.53 & 1.15 & \\
\hline & $35-39^{*}$ & 31 & 3.38 & 1.04 & & 3.07 & .99 & \\
\hline & $40+*$ & 19 & 3.62 & .88 & & $3.40 *$ & .99 & \\
\hline \multirow{5}{*}{ Education } & High school & 35 & 2.66 & 1.10 & \multirow{5}{*}{$\begin{array}{l}F(4,184)= \\
4.12 \\
p<.005\end{array}$} & $2.92 *$ & 1.22 & \multirow{5}{*}{$\begin{array}{l}F(4,184)= \\
2.38 \\
p<.05\end{array}$} \\
\hline & Associated d. & 57 & 2.80 & 1.12 & & $2.61 *$ & 1.00 & \\
\hline & Undergraduate & 47 & 2.76 & 1.21 & & $2.81 *$ & .90 & \\
\hline & Masters* & 31 & 3.38 & 1.04 & & 3.20 & .85 & \\
\hline & Doctoral* & 19 & 3.61 & .88 & & $3.46^{*}$ & .79 & \\
\hline \multirow{3}{*}{ Occupation } & Office m. & 45 & 3.30 & 1.00 & \multirow{3}{*}{$\begin{array}{l}F(3,185)= \\
18.38 \\
p<.001\end{array}$} & 3.33 & 1.03 & \multirow{3}{*}{$\begin{array}{l}F(3,185)= \\
17.91 \\
p<.001\end{array}$} \\
\hline & Secretaries* & 113 & 2.58 & 1.07 & & $2.45 *$ & .92 & \\
\hline & Executive ass. & 31 & 3.74 & 1.02 & & 3.25 & .98 & \\
\hline \multirow{2}{*}{ Sector } & Public & 90 & 2.78 & 1.16 & \multirow{2}{*}{$\begin{array}{l}\text { Not } \\
\text { significant }\end{array}$} & 2.72 & 1.03 & \multirow{2}{*}{$\begin{array}{l}\text { Not } \\
\text { significant }\end{array}$} \\
\hline & Private & 99 & 3.08 & 1.11 & & 2.86 & 1.06 & \\
\hline \multirow{3}{*}{ Institution } & Education & 26 & 3.58 & .745 & \multirow{3}{*}{$\begin{array}{l}F(3,185)= \\
20.56 \\
p<.001\end{array}$} & 3.32 & 1.02 & \multirow{3}{*}{$\begin{array}{l}F(3,185)= \\
18.46 \\
p<.001\end{array}$} \\
\hline & Service & 70 & 3.35 & 1.12 & & 3.16 & .98 & \\
\hline & Health* & 93 & 2.45 & 1.04 & & $2.37 *$ & .92 & \\
\hline \multirow{4}{*}{$\begin{array}{l}\text { Years in } \\
\text { occupation }\end{array}$} & $1-5$ & 86 & 2.77 & 1.08 & \multirow{4}{*}{$\begin{array}{l}\text { Not } \\
\text { significant }\end{array}$} & $2.68^{*}$ & .88 & \multirow{4}{*}{ Not tested } \\
\hline & $6-10$ & 53 & 2.91 & 1.32 & & $2.69 *$ & 1.17 & \\
\hline & $11-15$ & 31 & 3.26 & 1.13 & & 2.94 & 1.21 & \\
\hline & 16 and more & 19 & 3.26 & .78 & & $3.36^{*}$ & .88 & \\
\hline & $1-5$ & 117 & 2.75 & 1.07 & & 3.32 & 1.02 & \\
\hline Years in & $6-10$ & 39 & 3.04 & 1.39 & $\begin{array}{l}F(3,185)= \\
455\end{array}$ & 3.16 & .98 & $\begin{array}{l}F(3,185)= \\
1846\end{array}$ \\
\hline present org. & $11-15^{*}$ & 18 & 3.72 & .88 & & 2.37 & .92 & \\
\hline & 16 and more & 15 & 3.22 & .80 & & 3.32 & 1.02 & P..001 \\
\hline
\end{tabular}




\section{Discussion and Limitations}

This study aimed to explore the impact of top down communication on career satisfaction. Demographic data were collected too. Top-down communication and career satisfaction are significantly and positively correlated. Top-down communication scores were categorized as low and high group depending on the median score. Employees in the high top-down communication group $(\mathrm{M}=3.23, \mathrm{SD}=1.04)$ experience significantly more career satisfaction compared to low top-down communication group $(\mathrm{M}=2.37, \mathrm{SD}=.84)$. Top-down communication explains $20.9 \%$ of the variance on career satisfaction. Institution explains additionally $4.7 \%$ variance on career satisfaction.

Top-down communication could serve a kind of organizational support (Hagedorn \& Labovitz, 1968; Miller, 1975). Rhodes and Eisenberger (2002) claimed that managerial support is one of the main antecedent of organizational support. Why organizational support behaviors, like positive top-down communication have positive organizational and individual outcomes? Topdown communication decreases uncertainty and increases recognition and motivation. It satisfies both individual and organizational needs. Perrewe and Carlson (2002) showed that managerial support as a part of organizational support is positively correlated with job satisfaction. Koeske et al. (1994) reported that individuals pay attention to the organizational evaluations about themselves and the value given by organizations for their efforts. Top-down communication provides feedback for employee to evaluate himself and his performance. Wicks (2005), pointed out that, only listening the employee without being able to solve his/her problems and conveying positive feedback and appreciation is important (cited in Demirhan, Kula \& Karagöz, 2014).

Positive top-down communication creates positive thoughts and feelings towards organizational evaluations. If an employee has communication problems with his/her supervisor, satisfaction in most job related issues could not be experienced. Leader-member exchange theory suggests this.

Career development, proactive personality and career management behaviors were all positively related to career satisfaction (Barnett \& Bradley, 2007). Aktaş (2014) reported that career satisfaction is positively correlated with affective and normative commitment to occupational.Similarly, Turunç and Çelik (2010) found that perceived organizational support 
effects both organizational identification and job performance. Organizational identification is defined as psychological link between organization and employees, which could be associated with satisfaction. 


\section{References}

Aktas, H. (2014). Relationship between career satisfaction and occupational commitment in the context of career stages with demographic variables: Research on office managers, executive assistants and secretaries. International Journal of Social Science, 26, 195212.

Allen, M. W., Gotcher, J. M., \& Seibert, J. H. (1993). A decade of organizational communication research: Journal articles 1980-1991. In S. A. Deetz (Ed.) Communication Yearbook, 16, 252-230. New-bury Park: Sage.

Avcı, U., \& Turunç, Ö. (2012). Dönüşümcü liderlik ve örgüte güvenin kariyer memnuniyetine etkisi: Lider-üye etkileşiminin aracılık rolü. Uluslararası Alanya İşletme Fakültesi Dergisi, 4(2), 45-55.

Baker, K. (2002). Organizational communication. Chapter 13. Retrieved from http://www.au.af.mil/au/awc/ awcgate/doe/benchmark/ch13.pdf

Barnett, B. R., \& Bradley, L. (2007). The impact of organisational support for career development on career satisfaction. Career Development International, 12(7), 617636.

Brandes, L., \& Darai, D. (2014). The value of top-down communication for organizational performance. Univeristy of Zurich, Department of Economics, Working Paper No. 157.

Business Dictionary. (2015). Retrieved from http://www.businessdictionary.com/definition/ organizationalcommunication.html\#ixzz3XgV16bkp

Commgap. (2008). Organizational communication.http://siteresources.worldbank.org/ EXTGOVACC/ Resources/OrganizationalCommweb.pdf.

Deetz, S. (2000). Conceptual foundations. In F. M. Jablin \& L. L. Putnam (Eds). The new handbook of organizational communication: Advanced in theory, research, and methods (pp. 3-46). New-bury Park: Sage.

Demirhan, Y., Kula, S., \& Karagöz, G. (2014). The effect of job satisfaction and supervisor support on performance: The example of special operations police unit of Diyarbakır province. Süleyman Demirel University The Journal of Faculty of Economics and Administrative Sciences, 19(1), 285-297.

Downs, C. W., \& Hazen, M. D. (1977). A factor analytic study of communication satisfaction. Journal of Business Communication, 14(3), 63-73.

Friebel, G., \& Raith, M. (2004). Abuse of authority and hierarchical communication. RAND Journal of Economics, 35(2), 224-244. 
Greenhaus, J. H., Parasuraman, S., \& Wormley, W. M. (1990). Effects of race on organizational experiences, job performance evaluations, and career outcomes. Academy of Management Journal, 33, 64-86. doi:10.2307/256352

Greenhaus, J. H., Parasuraman S., \& Wormley, W. M. (1990). Effects of race on organizational experiences, job performance evaluations, and career outcomes. The Academy of Management Journal, 33(1), 64-86.

Hahn, L. K., Lippert, L., \& Paynton, S. T. (2014). Survey of Communication Study: Chapter 11. Organizational Communication. http://www.saylor.org/site/wpcontent/uploads/ 2013/02/BUS209-6.1.1-OrganizationalCommunication.pdf

Jablin, F. M. (1980). Superior's upward influence, satisfaction, and openness in superiorsubordinate communication: A re-examination of the Pelz effect. Human Communication European Scientific Journal, 6(3), 210-220.

Joo, B. K., \& Park, S. (2010). Career satisfaction, organizational commitment, and turnover intention: The effects of goal orientation, organizational learning culture and developmental feedback. Leadership \& Organization Development Journal, 31(6), 482-500.

Koeske, G. F., Kırk, S. A., Koeske, R. D., \& Rauktis, M. D. (1994). Measuring the monday blues: Validation of job satisfaction scale for the human service. Social Work Research, 18, 27-35.

Larkin, T., \& Larkin, S. (1994). Communicating Change: How to win support for new business directions. New York: McGraw-Hill.

Leigh, J., Kravitz, R.L. Schembri, M., Samuels, S. J., \& Mobley, S. (2002). Physicians' career satisfaction across specialties. ArchInternMed,162(14), 1577-1584. doi: 10.1001/archinte. 162.14.1577.

Morgan, B. S., \& William, A. S. (1983). Why internal communication is failing. Public Relation Journal, Relations Journal, 39(3), 15-17.

Perrewe, P. L., \& Carlson, D. S. (2002). Do men and women benefit from social support equally? Results from a field examination within the work and family context. In D. L. Nelson \& D. S. Burke (Eds.), Gender, Work, Stress and Health: Current Research Issues. Washington, DC: American Psychological Association.

Putnam, L. L., \& Cheney, G. (1985). Organizational communication: Historical development and future directions. In T. W. Benson (Ed.). Speech communication in the 20th century (pp. 130-156). Carbondale, IL: Southern University Press. 
Rhoades, L., \& Eisenberger, R. (2002). Perceived organizational support: A review of the literature. Journal of Applied Psychology, 87, 698-714.

Richmond, V. P., McCroskey, J. C., \&McCroskey, L. L. (2005). Organizational communication for survival: Making work, work (3rd edition). Boston: Allyn \& Bacon.

Rubin, R.B., \& Rubin, A.M. (1992). Antecedents of interpersonal communication motivation. Communication Quarterly, 40(3), 305-317.

Simsek, E. (2011). The role of organizational communication and personality trait on organizational communication satisfaction (Unpublished doctoral thesis). Eskişehir: Graduate School of Social Sciences of Anadolu University.

Turunç Ö. \& Çelik, M. (2010). Çalışanların algıladıkları örgütsel destek ve iş stresinin örgütsel özdeşleşme ve iş performansına etkisi. Yönetim ve Ekonomi, 17(2), 183-206.

Wicks, R. J. (2005). Overcoming secondary stress in medical and nursing practice: A guide to professional resilience and personal well-being. New York: Oxford University Press.

Yüksel, İ., (2005). İş-aile çatışmasının kariyer tatmini, iş tatmini ve iş davranışları ile ilişkisi. Atatürk Üniversitesi İktisadi ve İdari Bilimler Dergisi, 19(2), 301-314. 